\title{
Glossary and abbreviations
}

Alter-Europeanism New left perspective on EU/Eurozone created by crisis

DiEM25 Democracy in Europe Movement 2025

ECB European Central Bank

EFSF European Financial Stability Facility

EGP European Green Party

EMU Economic and Monetary Union

EP

European Parliament

ESM European Stability Mechanism

EU European Union

Eurozone 'Euro area' is the monetary union of 19 of $28 \mathrm{EU}$ member states under the monetary authority of the Eurosystem and under political control of Eurogroup

Fiscal Compact see TSCG

GDP gross domestic product

Greens-EFA

Greens-European Free Alliance, or G-EFA

GUE-NGL

IMF European United Left-Nordic Green Left

International Monetary Fund

Lexit

$\mathrm{MoU}$

'Left Exit' from the EU and/or the Eurozone

Memorandum of Understanding

OECD

Organisation for Economic Co-operation and

Development

PEL Party of the European Left

PES Party of European Socialists

S\&D Progressive Alliance of Socialists and Democrats (European Parliament)

troika An economic oversight committee consisting of representatives of the European Commission, ECB and IMF established to supervise the economic 
affairs of countries in receipt of emergency 'bailout' loans from those institutions and/or other European governments

TSCG Treaty on Stability, Coordination and Governance, also often referred to as the Fiscal Stability Treaty, European Fiscal Compact or Fiscal Compact

TTIP Transatlantic Trade and Investment Partnership

WTO World Trade Organization

Translations into English from original sources have been carried out by the relevant chapter authors. 